VARIABEL VOL. 1 NO. 2 (2018): 51-59

p-ISSN: 2593-302X dan e-ISSN: 2599-3038

This work is licensed under

a Creative Commons Attribution-NonCommercial 4.0 International License.

\title{
Pengaruh Model Problem Based Learning Terhadap Higher Order Thinking Skills Peserta Didik SMA Negeri di Kota Singkawang pada Materi Hukum Archimedes
}

Falwi Uji Flamboyant ${ }^{1}$, Eka Murdani ${ }^{2}$, Soeharto ${ }^{3}$

STKIP Singkawang, Kota Singkawang, Indonesia

muhammadfalwiujiflamboyant@ gmail.com ${ }^{1}$, ekamurdani@ gmail.com², soehartofisika@gmail.com ${ }^{3}$

\begin{tabular}{ll}
\hline \hline Kata Kunci: & ABSTRAK \\
Problem Based Learning, & Penelitian ini bertujuan untuk: (1) mendeskripsikan \\
Higher Order Thinking Skills, & Higher Order Thinking Skills (HOTS) peserta didik setelah \\
Hukum Archimedes & diterapkannya model Problem Based Learning (PBL), (2) \\
& mengetahui persentase HOTS peserta didik sebelum dan \\
& setelah diterapkannya model PBL, dan (3) mengetahui \\
pengaruh PBL terhadap HOTS peserta didik pada materi & hukum Archimedes. Jenis penelitian ini merupakan \\
penelitian kuantitatif eksperimen dengan desain penelitian \\
pre-experimental dan jenis desain one group pretest- \\
posttest. Populasi dalam penelitian ini adalah seluruh \\
peserta didik kelas XI IPA dengan teknik pengambilan \\
sampel purposive sampling dengan jumlah sampel \\
sebanyak 23 orang. Instrumen yang digunakan berupa tes \\
HOTS yang sebelumnya telah diujicobakan dengan \\
reliabilitas sebesar 0,65. Deskripsi HOTS peserta didik \\
dianalisis menggunakan Rasch Model diperoleh bahwa \\
kemampuan menganalisis merupakan kemampuan yang \\
paling banyak dikuasai oleh peserta didik, diikuti oleh \\
kemampuan mencipta, dan terakhir kemampuan \\
mengevaluasi. Persentase HOTS peserta didik dianalisis \\
menggunakan aplikasi Microsoft Excel diperoleh bahwa \\
kemampuan menganalisis dan mencipta mengalami \\
peningkatan sebesar 2,72\%, dan kemampuan \\
mengevaluasi mengalami peningkatan sebesar 6,16\%. \\
Sedangkan untuk mengetahui pengaruh model PBL \\
terhadap HOTS dianalisis menggunakan effect size, \\
diperoleh bahwa PBL memiliki pengaruh terhadap HOTS \\
peserta didik sebesar O.53 dengan kategori sedang.
\end{tabular}

\section{PENDAHULUAN}

Mutu pendidikan Indonesia di kancah dunia ternyata dikategorikan masih rendah. Pernyataan ini dibuktikan dari hasil survei yang dipublikasikan oleh Pearson pada tahun 2014 dengan judul The Learning Curve. Dari hasil survei tersebut diperoleh pendidikan di Indonesia berada di posisi terbawah 
VARIABEL Vol. 1 No. 2 (2018)

Page: $51-59$

(Z-score $=-1,84)$. Posisi Indonesia yakni berada di urutan 40 dari 40 negara yang dievaluasi (The Economic Intellegence Unit, 2014).

Secara umum soal-soal yang memiliki standar internasional memiliki karakteristik diantaranya: (1) mengukur kemampuan berpikir tingkat tinggi, (2) berbasis permasalahan kontekstual, dan (3) menggunakan bentuk tes yang beragam (Direktorat Pembinaan SMA, 2015). Menurut Direktorat Pembinaan SMA (2015) pada umumnya kemampuan peserta didik Indonesia sangat rendah pada beberapa hal, yaitu: (1) memahami informasi yang bersifat kompleks, (2) teori, analisis, dan pemecahan masalah; (3) pemakaian alat dan prosedur, dan (4) melakukan investigasi. Berdasarkan hasil survei yang telah dilakukan oleh Pearson dan pemaparan dari Direktorat Pembinaan SMA, maka dapat disimpulkan bahwa kemampuan berpikir tingkat tinggi peserta didik di Indonesia tergolong rendah di mana Indonesia hanya mampu menempati 10 peringkat terbawah.

Salah satu mata pelajaran yang diujikan oleh lembaga survei internasional yakni sains. Secara umum, sains dapat diartikan sebagai suatu ilmu yang mempelajari gejala alam. Sains terbagi menjadi beberapa cabang ilmu, salah satunya adalah fisika. Fisika merupakan ilmu yang mempelajari materi dan energi, hukum-hukum yang mengatur gerakan partikel dan gelombang, interaksi antarpartikel, sifat-sifat molekul, atom dan inti atom, dan sistem yang berskala lebih besar seperti gas, zat cair, dan zat padat (Tipler, 1998).

Menurut Permendikbud Nomor 21 Tahun 2016, dalam pembelajaran fisika, kompetensi yang harus dicapai yakni: (1) dapat mengembangkan sikap rasa ingin tahu, logis, kritis, dan analisis; dan (2) dapat merumuskan masalah, merumuskan hipotesis, menyimpulkan, serta mendesain dan melakukan eksperimen yang berkaitan dengan fisika. Dengan demikian dapat disimpulkan bahwa pembelajaran fisika haruslah menekankan kemampuan berpikir tingkat tinggi atau yang biasa dikenal dengan Higher Order Thinking Skills (HOTS). Hal ini dikarenakan kemampuan berpikir kritis, kemampuan menganalisis, kemampuan menyimpulkan, dan kemampuan mendesain eksperimen merupakan aplikasi dari HOTS.

Lemahnya pencapaian prestasi peserta didik Indonesia dapat dibuktikan dari hasil ujian Nasional, salah satunya yakni Ujian Nasional (UN) fisika. Berdasarkan hasil rekapitulasi nilai UN fisika peserta didik SMA di Kalimantan Barat yang dilakukan oleh Kemendikbud pada tahun 2015 menunjukkan bahwa rata-rata nilai UN fisika hanya sebesar 54,69, terendah dari tiga mata pelajaran sains atau ilmu pengetahuan alam (IPA) yang diujikan yakni kimia 58,55 dan biologi 55,3. Selain itu, berdasarkan hasil survei pendahuluan yang dilakukan Arifiyanti (2016) terhadap HOTS peserta didik SMA di Kalimantan Barat ditemukan bahwa HOTS peserta didik tergolong rendah dengan rata-rata persentase sebesar $52,26 \%$. Hal ini karena pembelajaran yang dilakukan selama ini hanya bersifat hafalan dan siswa tidak diberikan kesempatan untuk mengonstruk pengetahuannya sendiri, sehingga pembelajaran yang terjadi tidak bermakna (Sumarli, 2018; Sumarli et al., 2018). Menurut Ramos et al. (2013) dalam penelitiannya yang berjudul "Higher Order Thinking Skills and Academic Performance in Physics of College Students: A Regression Analysis" menunjukkan bahwa terdapat hubungan antara HOTS dengan prestasi akademik peserta didik di mana HOTS dapat mempengaruhi kemampuan fisika peserta didik dalam memecahkan permasalahan fisika.

Berdasarkan uraian-uraian yang telah dipaparkan di atas, maka dibutuhkan suatu solusi yang dapat meningkatkan HOTS peserta didik. Salah satu solusi yang dapat mengatasi permasalahan yang telah dipaparkan yakni dengan menerapkan suatu model pembelajaran yang dapat mengembangkan HOTS peserta didik. Model pembelajaran tersebut yakni Problem Based Learning (PBL). Menurut Rhem (1998) model pembelajaran PBL dapat diartikan sebagai model pembelajaran di mana peserta didik diberikan suatu permasalahan yang real, kontekstual dan mereka berusaha untuk menemukan pemecahannya. Selain itu, Menurut Arends (Suprihatiningrum, 2016) dalam pembelajaran PBL, peserta didik melakukan penyelidikan autentik untuk mencari penyelesaian nyata terhadap masalah nyata. Mereka harus menganalisis dan mendefinisikan masalah, mengembangkan hipotesis dan membuat ramalan, mengumpulkan dan menganalisis informasi, melakukan eksperimen (jika diperlukan), membuat inferensi dan merumuskan kesimpulan. Dengan demikian, dapat disimpulkan 
VARIABEL Vol. 1 No. 2 (2018)

Page: $51-59$

bahwa model PBL menekankan peserta didik untuk menggunakan HOTS. Hal ini dikarenakan melakukan analisis, melakukan eksperimen, membuat inferensi dan merumuskan kesimpulan merupakan bagian dari HOTS.

Dalam penerapannya, model pembelajaran PBL menekankan kepada peserta didik untuk memecahkan sendiri masalah yang akan diteliti, guru hanya bertindak sebagai fasilitator (Suparno, 2013). Model pembelajaran PBL peneliti pilih dikarenakan tahapan-tahapan pembelajarannya telah mencerminkan pembelajaran yang menekankan HOTS. Adapun sintaks dari model pembelajaran PBL menggunakan sintaks versi Eggen \& Kauchak (2012) yakni: (1) guru mereview pengetahuan awal yang dibutuhkan dan menyajikan masalah yang real dan kontekstual, (2) peserta didik menyusun startegi untuk memecahkan masalah dan guru memberikan umpan balik mengenai strategi tersebut, (3) peserta didik menerapkan strategi yang telah dirancang sebelumnya, dan (4) peserta didik dibimbing oleh guru membahas dan mengevaluasi hasil penyelidikan yang telah dilakukan. Selain karena tahapan-tahapan pembelajarannya, peneliti memilih model pembelajaran ini juga berdasarkan hasil temuan Hidayati (2017) dan Jayanti et al. (2016) yang menyatakan bahwa terjadi peningkatan HOTS peserta didik setelah diterapkannya model pembelajaran PBL.

Berdasarkan data-data dan kajian penelitian yang relevan yang telah disampaikan, maka penelitian ini diberi judul "Pengaruh Model Problem Based Learning Terhadap Higher Order Thinking Skills Peserta Didik SMA Negeri di Kota Singkawang pada Materi Hukum Archimedes". Materi hukum Archimedes dipilih dikarenakan aplikasi dari hukum Archimedes sangat banyak ditemukan di kehidupan sehari-hari dan sangat mudah untuk diterapkan. Diharapkan melalui penelitian ini dapat memberikan gambaran mengenai pengaruh model pembelajaran PBL terhadap HOTS peserta didik khususnya pada materi hukum Archimedes dan menambah bahan refrensi bagi peneliti selanjutnya mengenai model pembelajaran PBL terhadap HOTS peserta didik.

\section{METODE PENELITIAN}

Jenis penelitian ini merupakan penelitian kuantitatif dengan metode eksperimen. Desain penelitian ini adalah pre-experimental dengan jenis desain one group pretest-posttest. Peserta didik diberi soal pretest, selanjutnya diberi treatment/perlakuan berupa penerapan model PBL, langkah terakhir adalah pemberian lembar soal post-test pada peserta didik.

Populasi dalam penelitian ini adalah seluruh peserta didik kelas XI IPA. Teknik pengambilan sampel menggunakan purposive sampling dengan jumlah sampel sebanyak 23 orang. Instrumen yang digunakan berupa tes HOTS. Deskripsi HOTS peserta didik dianalisis menggunakan Rasch Model. Persentase HOTS peserta didik dianalisis menggunakan aplikasi Microsoft Excel, dengan menggunakan persamaan (1).

$$
\text { Aspek }- \text { aspek HOTS }=\frac{x}{y} \times 100 \%
$$

Keterangan:

X : Jumlah bobot nilai butir soal HOTS seluruh peserta didik

Y : Jumlah bobot nilai maksimum butir soal HOTS seluruh peserta didik

Sedangkan untuk mengetahui pengaruh model PBL terhadap HOTS dianalisis menggunakan effect size, dengan menggunakan persamaan (2).

$$
d=\frac{M_{\text {posttest }}-M_{\text {pretest }}}{\sqrt{\frac{S D_{\text {posttest }}^{2}+S D_{\text {pretest }}^{2}}{2}}}
$$


$d$ adalah nilai effect size, $M$ adalah rata-rata skor tes, dan $S D$ standar deviasi skor tes (Dunst, Hamby, \& Trivette; 2014) Adapun batas-batas tingkat pengaruh penggunaan model pembelajaran PBL terhadap HOTS peserta didik dapat dilihat pada Tabel 1 (Salkind, 2007).

Tabel 1. Kriteria Effect Size

\begin{tabular}{cc}
\hline Effect Size $(\boldsymbol{d})$ yang Diperoleh & Kriteria \\
\hline$d>0,7$ & Besar \\
$0,5 \leq d \leq 0,7$ & Sedang \\
$0,2 \leq d<0,5$ & Kecil \\
$d<0,2$ & Tidak ada efek \\
\hline
\end{tabular}

\section{HASIL DAN PEMBAHASAN}

Berdasarkan penelitian yang telah dilakukan, hasil analisis butir soal yang akan dipaparkan dalam penelitian ini meliputi: (1) deskripsi HOTS peserta didik setelah diterapkannya model PBL, (2) persentase HOTS peserta didik sebelum dan sesudah diterapkannya model PBL, dan (3) pengaruh model PBL terhadap HOTS peserta didik.

\section{Deskripsi HOTS Peserta Didik Sebelum dan Sesudah Diterapkannya Model PBL}

Deskripsi HOTS peserta didik setelah diterapkannya model PBL diperoleh dari analisi butir soal posttest yang telah dikerjakan peserta didik. Analisis butir soal tersebut menggunakan Rasch Model berbantuan aplikasi Ministep 4.0.1. Adapun hasil dari analisis data tersebut yang akan dideskripsikan meliputi sebaran tingkat kesulitan butir soal, sebaran tingkat abilitas peserta didik, dan sebaran tingkat kesesuaian individu terhadap kemampuan yang dimiliki.

\section{a. Sebaran Tingkat Kesulitan Butir Soal (Item Measure)}

Berdasarkan analisis butir soal dengan menggunakan Rasch Model berbantuan aplikasi Ministep 4.1.0, diperoleh sebaran tingkat kesulitan butir soal yang ditunjukkan oleh tabel item measure. Adapun tabel dari item measure yang menunjukkan tingkat kesulitan butir soal dapat dilihat pada Gambar 1.

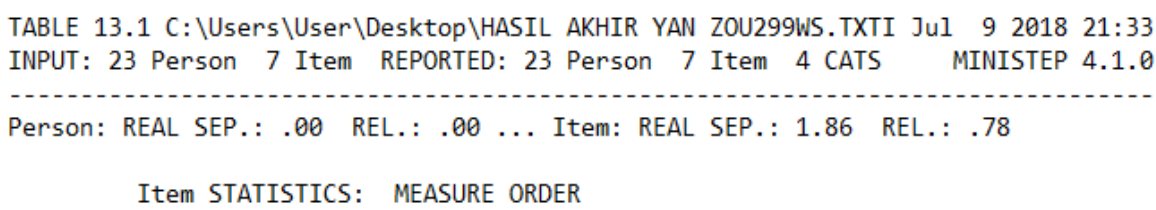

\begin{tabular}{|c|c|c|c|c|c|c|c|c|c|c|c|c|c|}
\hline \multirow{3}{*}{$\begin{array}{l}\text { ENTRY } \\
\text { NUMBER }\end{array}$} & TOTAL & TOTAL & & MODEL & \multicolumn{2}{|c|}{ INFIT } & \multicolumn{2}{|c|}{ OUTFIT } & \multicolumn{4}{|c|}{ |PTMEASUR-AL |EXACT MATCH| } & \multirow[b]{2}{*}{ Item } \\
\hline & SCORE & COUNT & MEASURE & S.E. I & |MNSQ & ZSTD & |MNSQ & ZSTD & |CORR. & EXP. I & OBS\% & EXP\%| & \\
\hline & & & & & & & & ---+ & & $\cdots+$ & & $\cdots-1$ & \\
\hline 5 & 29 & 23 & .95 & .38 & .96 & .1 & | 1.02 & .2 & .10 & $.22 \mid$ & 78.3 & 79.5 & S5 \\
\hline 6 & 30 & 23 & .82 & .35 & 1.27 & .7 & 1.02 & .2 & .24 & $.23 \mid$ & 73.9 & 73.5 & S6 \\
\hline 2 & 40 & 23 & .00 & .24 & 1.02 & .2 & .94 & $-.1 \mid$ & .53 & .35 & 43.5 & $44.3 \mid$ & $\mathrm{S} 2$ \\
\hline 1 & 42 & 23 & -.12 & .24 & .65 & -1.5 & .60 & -1.5 & .62 & $.37 \mid$ & 39.1 & 38.0 & S1 \\
\hline 4 & 45 & 23 & -.28 & .23 & |.97 & .0 & | 1.12 & .5 & .30 & $.38 \mid$ & 17.4 & $37.6 \mid$ & S4 \\
\hline 7 & 53 & 23 & -.67 & .22 & 1.43 & 1.7 & 1.46 & 1.8 & .21 & $.41 \mid$ & 13.0 & 32.2 & 57 \\
\hline 3 & 54 & 23 & -.71 & .22 & | .85 & -.6 & | .84 & $-.6 \mid$ & .38 & $.41 \mid$ & 47.8 & 32.4 & $\$ 3$ \\
\hline & 41.9 & 23.0 & .00 & $.27 \mid$ & |1.02 & .1 & 1.00 & |1| & & & 44.7 & $48.2 \mid$ & \\
\hline P.SD & 9.2 & .0 & .61 & .06 & .24 & .9 & .24 & .9 & & & 23.2 & $18.3 \mid$ & \\
\hline
\end{tabular}

Gambar 1. Screenshot Output dari Item Measure

Pada kolom total count terbaca ada angka 23. Ini menunjukkan semua peserta didik menjawab butir soal. Selain itu, informasi lain yang dapat diperoleh dari Gambar 1. adalah pengurutan tingkat kesulitan butir soal dari yang tertinggi, ditunjukkan oleh butir soal dengan kode S5 hingga ke butir soal yang terendah, ditunjukkan oleh butir soal dengan kode S3, yang ditunjukkan pada kolom measure. 
Pada Gambar 1., jika nilai deviasi standar pada kolom measure $(0,61)$ dikombinasikan dengan ratarata logit pada kolom measure $(0,0)$ maka akan diperoleh pengelompokkan tingkat kesulitan butir soal butir soal dari yang sulit hingga yang termudah yang ditunjukka pada Tabel 2.

\begin{tabular}{lll}
\multicolumn{3}{c}{ Tabel 2. Tingkat Kesulitan Butir Soal (Item Measure) } \\
\hline Nilai Logit Soal (S) & Keterangan & Butir Soal \\
\hline$S>0,61$ & Sulit & 5,6 \\
$0,0 \leq S \leq 0,61$ & Sedang & 2 \\
$S<0,0$ & Mudah & $1,4,7,3$ \\
\hline
\end{tabular}

b. Sebaran Tingkat Abilitas Peserta Didik (Person Measure)

Untuk sebaran tingkat abilitas peserta didik, analisis dengan Rasch Model berbantuan aplikasi Ministep 4.0.1 ditunjukkan oleh tabel item measure. Adapun tabel dari person measure yang menunjukkan sebaran tingkat abilitas peserta didik dapat dilihat pada Gambar 2.

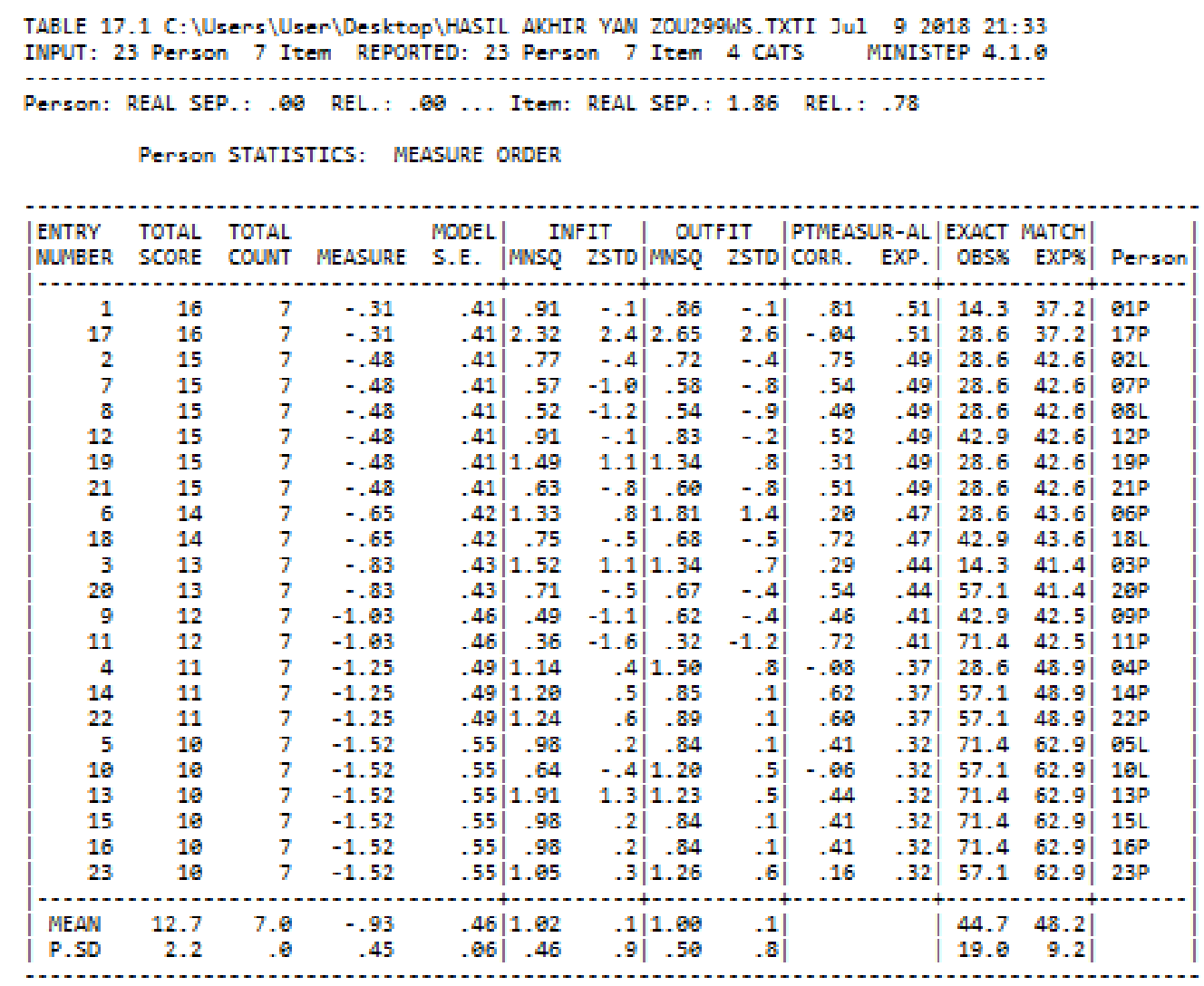

Gambar 2. Screenshot Sebaran Tingkat Abilitas Peserta Didik

Berdasarkan Gambar 2, dapat diketahui bahwa HOTS peserta didik berada di bawah rata-rata tingkat standar kesukaran soal dengan nilai logit sebesar $-0,93$. Selain itu, dapat diketahui pula bahwa peserta didik yang memiliki HOTS tertinggi adalah peserta didik dengan kode 01 P. Sedangkan peserta didik yang memiliki HOTS terendah adalah peserta didik dengan kode 23 P. Jika abilitas ini dikelompokkan maka diperoleh pengelompokkan abilitas peserta didik seperti pada Tabel 3.

Tabel 3. Tingkat Abilitas Peserta Didik

\begin{tabular}{ll}
\hline Nilai Logit Abilitas Peserta Didik (A) & Keterangan \\
\hline$A>0,45$ & Tinggi \\
$-0,93 \leq A \leq 0,45$ & Sedang \\
$A<-0,93$ & Rendah \\
\hline
\end{tabular}




\section{c. Sebaran Tingkat Kesesuaian Individu Terhadap Kemampuan yang Dimiliki (Person Fit Order)}

Berdasarkan analisis butir soal dengan menggunakan Rasch Model berbantuan aplikasi Ministep 4.1.0, diperoleh diperoleh pola respon peserta didik terhadap butir soal yang telah dijawabnya. Pola respon ini dapat dilihat pada tabel person fit order. Adapun tabel dari person fit order yang menunjukkan sebaran tingkat kesesuaian individu terhadap HOTS yang dimilikinya dapat dilihat pada Gambar 3.

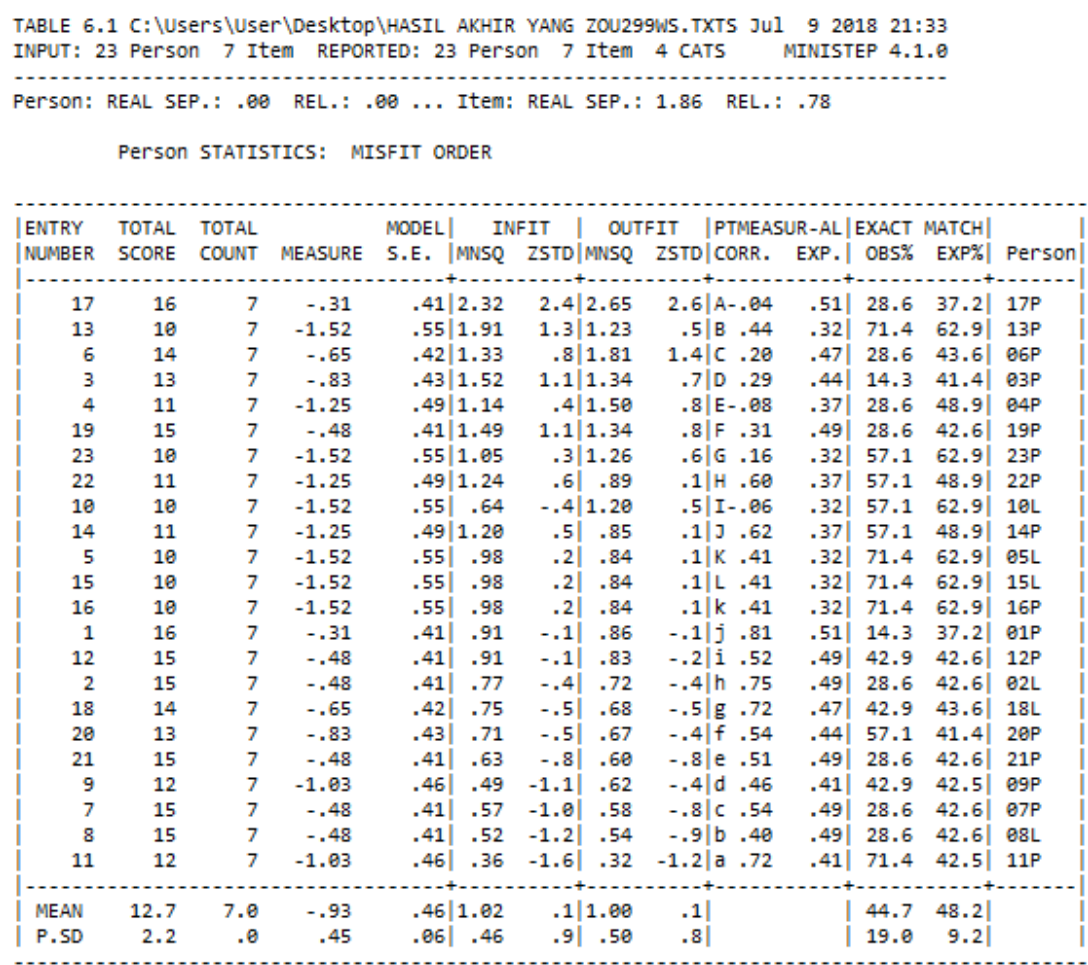

Gambar 3. Screenshot Sebaran Tingkat Kesesuaian Individu Terhadap Kemampuan yang Dimiliki

Pada Gambar 3, peserta didik yang tidak memenuhi 3 kriteria yakni outfit means-square (MNSQ), outfit z-standard (ZSTD), point measure correlation adalah peserta didik dengan kode $17 \mathrm{P}, 06 \mathrm{P}, 03$ P, 04 P, 19 P, 23 P, 10 L, dan 11 P. Hal ini mengindikasi adanya ketidakkonsistenan berpikir peserta didik dan ketidaksesuaian jawaban yang diberikan dengan abilitas yang dimiliki. Adapun untuk mengetahui lebih lanjut mengenai indikasi ini maka digunakan scalogram yang dapat dilihat pada Gambar 4.

Pada Gambar 4, peserta didik dengan kode $17 \mathrm{P}$ termasuk kategori peserta didik yang kurang cermat. Hal ini dikarenakan pada soal yang tidak begitu sulit ia salah dalam menjawabnya. Sedangkan soal yang cukup sulit ia mampu menjawabnya walapun ada yang kurang tepat. Sedangkan untuk peserta didik dengan kode $19 \mathrm{P}$ disamping tidak cermat (tidak dapat menjawab soal yang paling mudah dengan tepat), ia malah dapat mengerjakan soal yang lebih sulit dimana jawabannya hampir tepat. Hal ini mengindikasi peserta didik dengan kode $19 \mathrm{P}$ kurang cermat dalam memahami butir soal.

Dari hasil analisis data yang telah dilakukan diperoleh bahwa HOTS peserta didik berada di bawah rata-rata tingkat standar kesukaran soal. Hal ini dibuktikan dengan nilai logit peserta $(-0,93)$ didik yang dibawah standar rata-rata nilai logit butir soal $(0,0)$. Berdasarkan analisis data menunjukkan bahwa peserta didik tidak konsisten dalam menjawab butir soal dan memiliki kecenderungan kurang memahami butir soal dengan baik. Hal ini mengindikasi bahwa ada beberapa peserta didik yang kurang memaksimalkan abilitasnya, kurang cermat dalam mengerjakan butir soal, terjadinya kecurangan dalam mengerjakan, atau adanya tebakan (lucky guess). Dari hasil analisis scalogram ditemukan bahwa kebanyakan peserta didik kurang cermat dalam mengerjakan butir soal dan memiliki permasalahan dalam proses perhitungan dikarenakan pada soal mengevaluasi butir soal dalam bentuk perhitungan. 


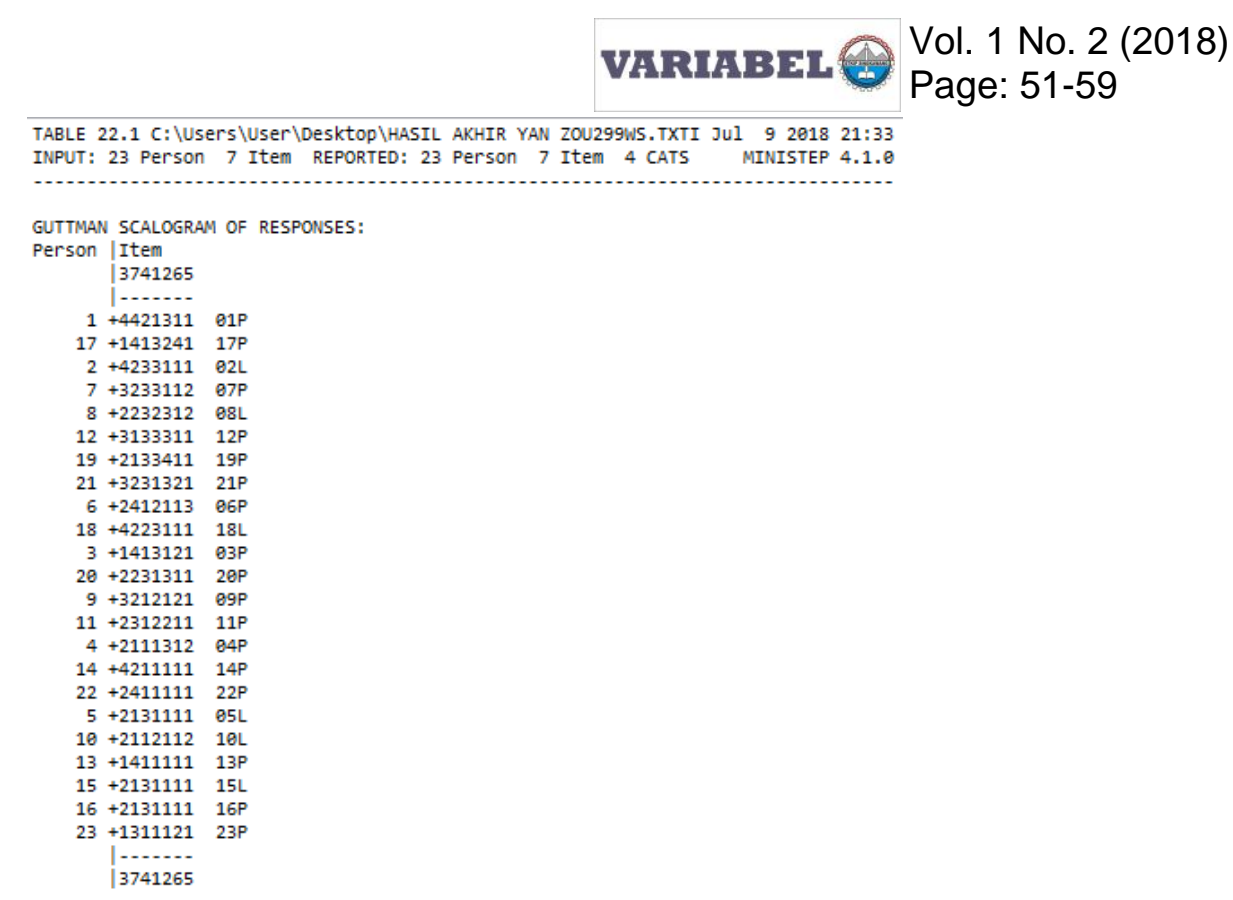

Gambar 4. Scalogram

Hasil dari analisis data penelitian menunjukkan bahwa sebagaian besar peserta didik lemah dikemampuan mengevaluasi. Hal ini dibuktikan dengan butir soal yang paling sulit dan banyak sekali peserta didik yang menjawab salah ditunjukkan oleh butir soal dengan kode S2, S5, S6 dengan S5 merupakan soal yang tersulit dan kesemua butir soal tersebut merupakan soal dalam kategori mengevaluasi. Dari pola yang ditunjukkan scalogram dan juga butir soal yang diberikan terlihat bahwa sebagian besar peserta didik kesulitan dalam proses perhitungan.

Kemampuan HOTS tertinggi ditunjukkan oleh kemampuan menganalisis, dimana hampir sebagian peserta didik menjawab dengan tepat, hanya saja ada beberapa peserta didik kurang cermat dalam mengerjakan butir soal. Hal ini dibuktikan dengan banyaknya peserta didik yang menjawab hampir tepat butir soal dengan kode S3, S7 dengan S3 merupakan soal termudah dan kesemua butir soal tersebut merupakan soal dalam kategori menganalisis. Kemudian diikuti oleh kemampuan mencipta. Berdasarkan analisis scalogram didapati bahwa sebagaian peserta didik mengalami permasalahan dalam memformulasikan persamaan fisika tetapi memahami konsepnya.

Persentase HOTS Peserta Didik Sebelum dan Sesudah Diterapkannya Model PBL

Berikut ini disajikan Gambar 5 yang menunjukkan grafik persentase HOTS peserta didik sebelum dan sesudah diterapkannya PBL, yang dianalisis dengan bantuan aplikasi Microsoft Excel 2013.

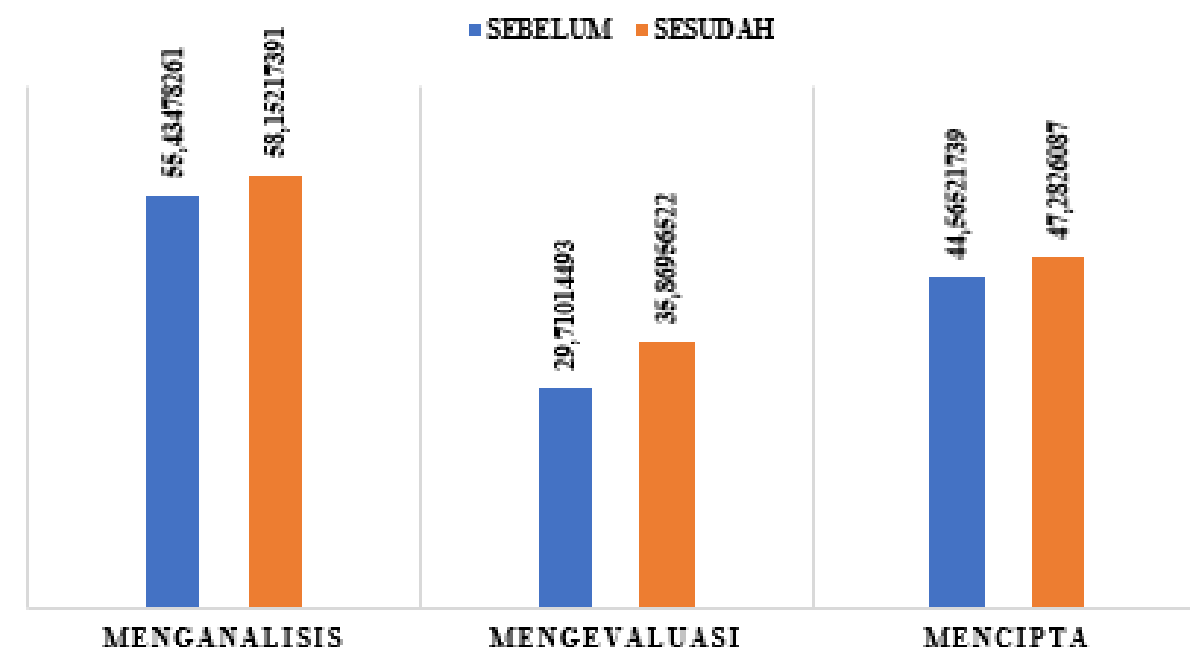

Gambar 5. Persentase HOTS Peserta Didik Sebelum dan Sesudah Diterapkan PBL 
Berdasarkan Gambar 5, didapati bahwa seluruh aspek HOTS mengalami peningkatan yaitu: (1) aspek menganalisis, dari 55,43 \% menjadi 58,15\%.; (2) aspek mengevaluasi, dari 29,71\% menjadi 35,87 $\%$; dan (3) aspek mencipta, dari 44,57 \% menjadi 47,28\%. Dengan demikian, penelitian ini memiliki hasil yang sama dengan penelitian yang telah dilakukan oleh Hidayati (2017) dan Jayanti dkk. (2016) yang menyatakan bahwa terjadi peningkatan HOTS peserta didik setelah diterapkannya model PBL.

\section{Pengaruh Model PBL Terhadap HOTS Peserta Didik}

Berdasarkan analisis effect size yang telah dilakukan maka diperoleh bahwa model PBL mempengaruhi HOTS peserta didik pada materi hukum Archimedes. Hal ini dikarenakan tahapantahapan model pembelajaran PBL telah mencerminkan pembelajaran berbasis HOTS. Menurut Arends (dalam Suprihatiningrum, 2016) dalam pembelajaran PBL, peserta didik melakukan penyelidikan autentik untuk mencari penyelesaian nyata terhadap masalah nyata. Mereka harus menganalisis dan mendefinisikan masalah, mengembangkan hipotesis dan membuat ramalan, mengumpulkan dan menganalisis informasi, melakukan eksperimen (jika diperlukan), membuat inferensi dan merumuskan kesimpulan.

Dari pemaparan di atas terlihat bahwa model PBL menekankan peserta didik untuk menggunakan HOTS. Hal ini dikarenakan melakukan analisis, inferensi, melakukan eksperimen membuat inferensi dan merumuskan kesimpulan merupakan bagian dari HOTS. Sehingga, hasil yang diharapkan dari model PBL adalah dapat memberikan pengaruh terhadap HOTS peserta didik. Adapun besarnya pengaruh model PBL terhadap HOTS peserta didik pada penelitian ini yang diperoleh dari analisis effect size sebesar 0,53 dalam kategori sedang.

\section{KESIMPULAN}

Kesimpulan dari penelitian ini adalah deskripsi HOTS peserta didik setalah diterapkannya model PBL yaitu: (1) HOTS peserta didik berada di bawah rata-rata tingkat standar kesukaran soal dengan nilai logit sebesar -0,93, (2) menganalisis merupakan kemampuan yang paling banyak dikuasai oleh peserta didik dengan nilai logit berturut-turut sebesar $-0,71$ dan $-0,67$ diikuti oleh kemampuan mencipta dengan nilai logit berturut-turut sebesar $-0,12$ dan -,028, terakhir kemampuan mengevaluasi dengan nilai logit berturut-turut sebesar $0,00,0,95$, dan 0,82; dan (3) sebagian besar peserta didik mengalami kesulitan pada saat memformulasikan persamaan fisika dan proses perhitungan. Persentase HOTS peserta didik sebelum dan sesudah diterapkannya model PBL adalah: (1) aspek menganalisis, sebelumnya sebesar 55,43 \% menjadi 58,15\% (naik sebesar 2,72\%); (2) aspek mengevaluasi, sebelumnya sebesar 29,71 \% menjadi 35,87 \% (naik sebesar 6,16\%); dan (3) aspek mencipta, sebelumnya sebesar 44,57 \% menjadi 47,28\% (naik sebesar 2,72\%). Terdapat pengaruh penggunaan model Problem Based Learning (PBL) terhadap HOTS peserta didik pada meteri hukum Archimedes berdasarkan nilai effect size sebesar 0,53 dalam kategori sedang.

\section{UCAPAN TERIMA KASIH}

Ucapan terima kasih diberikan kepada Bapak Drs. Andi Mursidi, M.Si., selaku ketua STKIP Singkawang yang telah memfasilitasi penulis sehingga artikel ini dapat diterbitkan di berkala ilmiah STKIP Singkawang.

\section{DAFTAR PUSTAKA}

Arifiyanti, Fitria. (2016). Pengembangan Physics Comprehensive Contextual Teaching Material Berbasis KKNI Pada Materi Usaha dan Energi Untuk Meningkatkan Higher Order Thinking Skills dan Scientific attitude Peserta. Tesis. Yogyakarta: Program Pascasarjana Universitas Negeri Yogyakarta. Tidak Dipublikasikan.

Direktorat Pembinaan SMA. (2015). Penyusunan Soal Higher Order Thinking Skill's. Jakarta: Direktorat Jendral Pendidikan Menengah Kemendikbud.

Dunst, C.J., Hamby, D.W., \& Trivette, C.M. (2004). Guidelines for Calculating Effect Sizes for Practice-Based Research Syntheses. Evidence-Based Approaches to Early Childhood 
Development, 3(1).

Eggen, P., \& Kauhack, D. (2012). Starategi dan Model Pembelajaran Mengajarkan Konten dan Keterampilan Berpikir( Edisi Keenam). (Terjemahan Satrio Wahono). Jakarta: PT. Indeks.

Hidayati, A.U. (2017). Keefektifan Pendekatan Problem Based Learning dan Pendekatan Saintifik Ditinjau dari Higher Order Thinking Skills dan Karakter siswa Pada Materi Bangun Ruang Sisi Datar Kelas VIII SMP Semester Genap. Tesis. Yogyakarta: Program Pascasarjana Universitas Negeri Yogyakarta. Tidak Dipublikasikan.

Jayanti, R.A., dkk. (2016). Efektivitas Pembelajaran Fisika Model Problem Based Learning (PBL) Melalui Metode POE Terhadap Kemampuan Berpikir Tingkat Tinggi Peserta Didik. Prosiding Seminar Nasional Pendidikan, Program Studi Pendidikan Fisika Fakultas Tarbiyah Dan Keguruan IAIN Raden Intan Lampung. pp. 208-214.

Kemendikbud. (2016). Lampiran Permendikbud Nomor 21 Tahun 2016 Tentang Standar Isi Pendidikan Dasar dan Menengah. Jakarta: Kementerian Pendidikan dan Kebudayaan.

Kemendikbud. (2015). Hasil Ujian Nasional 2015. http://118.98.234.50/lhun/ grafik.aspx. (Diakses tanggal 27 Juli 2017).

Ramos, J.L.S., et al. (2013). Higher Order Thinking Skillss and Academic Performance in Physics of College Students: A Regression Analysis. International Journal of Innovative Interdisciplinary Research. 48-60.

Rhem, J. (1998). Problem-Based Learning: An Introduction. Dalam Featured Articles, 8(1).

Salkind, N.J. (2007). Encyclopedia Of Measurement And Statistics. California: Sage Publications Inc.

Sumarli, S. (2018). Analisis Model Pembelajaran Tipe Think-Pair-Share Berbasis Pemecahan Masalah Terhadap Keterampilan Berpikir Tingkat Tinggi Siswa. JIPF (Jurnal Ilmu Pendidikan Fisika), $3(1), 8-13$.

Sumarli, S., Nugroho, S. E., \& Yulianti, I. (2018). Keefektifan Model Pembelajaran Creative Problem Solving Berpendekatan Inquiry terhadap Keterampilan Proses Sains Siswa. Physics Communication, 2(1), 63-69.

Suparno, Paul S.J. (2013). Metodologi Pembelajaran Fisika Konstruktivistik dan Menyenangkan. Yogyakarta: Universitas Sanata Dharma.

Suprihatiningrum, J. (2016). Strategi Pembelajaran Teori dan Aplikasi. Yogyakarta: AR-Ruzz Media. The Economic Intellegence Unit. (2014). The Learning Curve Report. London: Pearson.

Tipler, Paul A. (1998). Fisika Untuk Sains dan Teknik Jilid 1. Jakarta: Penerbit Erlangga. 